\title{
Implications of corporal punishment on primary school children
}

\author{
Shukla Jyoti* \& Singh Neetu** \\ Research Scholar* \& Asst. Professor** \\ Department of Human Development \& Family Studies School for Home Sciences \\ Babasaheb Bhimrao Ambedkar University, Lucknow-226025 Uttar Pradesh, India
}

\begin{abstract}
The use of corporal punishment at home and school has been widely debated. Some believe it is a means of discipline while others call it abuse. Corporal punishment is harmful to children. It could lead to emotional and physical problems. Corporal punishment is so readily at hand that it discourages some teachers from trying alternatives .Corporal punishment is one teacher-child interaction harmful to children. Corporal punishment inhibits learning, interferes with the accomplishment of each of the important developmental tasks of children and their teachers, and has the potential for physical harm to the child. Corporal punishment should be considered as child abuse and prohibited in all our schools.
\end{abstract}

Key words: corporal punishment, emotional problem, physical problem.

\section{Introduction}

Corporal punishment refers to intentional application of physical pain as method of behavior change. It includes a wide variety of methods such as hitting, slapping, spanking, punching, kicking, pinching, shaking, shoving, choking, use of various objects (i.e., wooden paddles, belts, sticks, pins, or others), painful body postures (such as placing in closed spaces), use of electric shock, use of excessive exercise drills, or prevention of urine or stool elimination. The majority of children have experienced physical punishment by the time they reach adolescence ( Ritchie 1981).

(McGrath1999) claimed that corporal punishment is an assault on the dignity of individual and offensive act against the dignity of the teaching profession. In other study also proposed that corporal punishment reflects a failure on the part of the teachers.

Corporal punishment is prohibited in schools in the Right to Free and Compulsory Education Act 2009. Article 17 states: "(1) No child shall be subjected to physical punishment or mental harassment. (2) whoever contravenes the provisions of sub-section (1) shall be liable to disciplinary action under the service rules applicable to such person." The Right of Children to free and Compulsory Education Rules 2010 provide for implementation of the Act, including awareness raising about the rights in the Act, procedures for monitoring implementation, and complaints mechanisms when the rights are violated. However, the prohibition in the Act applies only to children aged 6-14. In some states, children in all schools are legally protected from corporal punishment under state laws - Goa (Goa Children's Act 2003, article 41), Andhra Pradesh (Education Rules 1966, amended 2002, rule 122) and Tamil Nadu (Education Rules, amended 2003, rule 51). In Delhi, provisions for corporal punishment in the Delhi School Education Act (1973) were struck down by the Delhi High Court in 2000, and in 2004 the Calcutta High Court ruled that caning in state schools in West Bengal was unlawful (RTE act 2009).

A study carried out by Child line India Foundation between 2009 and 2011 found that students experienced corporal punishment in almost $95 \%$ of the 198 schools in 11 states studied, despite it being prohibited. Only $6 \%$ of government schools studied and $4 \%$ of private schools studied were free of corporal punishment (Reported in India Today, 5 January 2012).

(Robinson, Funk, Beth, et.al, 2005) revealed that in United States and parts of Canada remain the only developed countries to allow corporal punishment.

Corporal punishment does not produce long-lasting changes in behavior; negatively effects the social, psychological, and educational development of students; contributes to the cycle of child abuse; and promotes proviolence attitudes of youth (Andero \& Stewart, 2002)

\section{Corporal punishment among school children}

Physical abuse in schools, also referred to as 'Corporal punishment', is the deliberate infliction of pain intended to change a person's behavior or to punish him/her. The debate about whether or not to use corporal punishment to discipline and teach a child is an old one. Countries like Singapore still use physical methods of discipline but across the globe there is a realization that the line between punishment and abuse is rather thin and blurred and that there are other more judicious and effective ways to enforce discipline than beatings. In India 
this debate is raging across schools and there is an attempt to raise awareness about the adverse effects on children of beatings in schools.

A study conducted by ministry of women and child development on child abuse in India 2007 to assess the incidence of physical abuse among school children, responses from a sample of 3163 children were taken. Questionnaires were used to a total number of 12,447 children. Of these, 3163 were school-going children because studying in school was their primary activity and founded that majority of children $(65.01 \%)$ reported being beaten at school, which means that two out of three children are victims of corporal punishment. Out of those reporting corporal punishment schools, $54.28 \%$ were boys and $45.72 \%$ were girl. Data also indicated the State wise percentage of children reporting corporal punishment-

\begin{tabular}{|l|l|c|}
\hline state & Yes \% & No\% \\
\hline Andhra pradesh & 50.03 & 46.96 \\
\hline Asam & 99.56 & .44 \\
\hline Bihar & 47.45 & 52.55 \\
\hline Dilhi & 69.11 & 39.89 \\
\hline Goa & 34.25 & 65.75 \\
\hline gujrat & 48.97 & 51.03 \\
\hline kerla & 57.58 & 42.42 \\
\hline Madhya Pradesh & 48.43 & 51.27 \\
\hline Maharastra & 79.90 & 24.10 \\
\hline Mijoram & 90.86 & 9.14 \\
\hline rajsthan & 17.87 & 82.13 \\
\hline Uttar Pradesh & 81.59 & 18.41 \\
\hline West Bengal & 55.56 & 44,44 \\
\hline total & 65.01 & 34.99 \\
\hline
\end{tabular}

It is revealed from the table that all states reported corporal punishment, higher percentage of corporal punishment (about $50 \%$ or more) was reported from eight States. Amongst these States while Assam and Mizoram reported $99.56 \%$ and $90.86 \%$ corporal punishment in schools respectively, Rajasthan reported the minimum (17.87\%). The figures for Rajasthan probably do not reflect the real position and it appears to be an anomaly when compared with the national trend. The other States reporting high incidences of corporal punishment included Uttar Pradesh (81.59\%), Maharashtra (75.90\%) and Delhi (69.11\%).

A study by the NGO Aapanach (2004) found that, of 350 children surveyed from public, private, and municipal schools, over 75 percent said that they received punishment at school, and nearly 60 percent said the most frequent form of punishment was caning or hitting with a ruler. It was common for the whole class to be punished (66 percent). A third (33 percent) reported cases of severe injury due to punishment (cities.expressindia.com,).

\section{Teacher's perception towards corporal punishment}

UNESCO (2001) reported that, many teachers in Kenya argue that without corporal punishment, schools would descend into chaos. Pupils would become even more unruly by the time they reached high school. According to this report, teachers contend that corporal punishment is one of the few disciplinary tools available to control large class sizes.

A study conducted by Johnson (2004) reported that many teachers often carry out corporal punishment to maintain discipline in schools without the knowledge of the headmaster.

Agbenyega (2006) reported on the practice of corporal punishment in two basic schools in the Greater Accra District in Ghana, founded that that an overwhelming majority of the teachers [94 and 98 percent] use corporal punishment to enforce school discipline. The results further indicate that the majority of the teachers in both school sites administer corporal punishment to students who perform poorly in academic work. This implies that students with special learning problems who are not officially identified may be punished often for poor performance. Another surprising aspect of this result is that a large number of teachers from all the schools indicate their unwillingness to discontinue corporal punishment in their schools.

a study conducted among pupils, teachers and Ministry of Education (MOE) in Kenya by Human Rights Watch (2007), and revealed that pupils described how some teachers continue to cane them while others resort to other forms of physical punishment such as standing in the hot sun with their hands in the air for several hours; kneeling on the ground for extended periods; slapping and pinching. In some instances, physical abuse by teachers has led to serious and lasting injuries. Teachers also punish children by giving them harsh tasks such as running long distances or uprooting tree stumps.

Gladwell (1999) survey of teachers' attitudes towards corporal punishment after its ban in schools in South Africa reported a sense of despair among teachers attributed mainly to the disruptive behavior of pupils and the perception among the teachers that their authority had been taken away. Such sentiments from the 
teachers show that they were not adequately prepared to maintain discipline in schools without corporal punishment.

\section{Consequences of Corporal Punishment}

Corporal punishment does not produce long-lasting changes in behavior; negatively effects the social, psychological, and educational development of students; contributes to the cycle of child abuse; and promotes proviolence attitudes of youth (Andero \& Stewart, 2002)

1. Physical health outcomes - An analysis of research on physical punishment of children over the past 20 years indicates that such punishment is potentially harmful to their long-term development.(Canadian Medical Association Journal).

A study shows that physical punishment is associated with increases in delinquency, antisocial behavior, and aggression in children, and decreases in the quality of the parent-child relationship, children's mental health, and children's capacity to internalize socially acceptable behavior. Adults who have been subjected to physical punishment as children are more likely to abuse their own child or spouse and to manifest criminal behavior (Gershoff 2008).

(Vygotsky 1978) stated that Corporal punishment may legitimize violence for children in interpersonal relationships because they tend to internalize the social relations they experience.

A study conducted in united state to assess the Corporal punishment and child adjustment and found that use of corporal punishment was associated with problems in both emotional and behavioral adjustment. However, these associations were strongest for children who experienced high levels of corporal punishment, for children who were impulsive, and for children who did not experience a warm and supportive family climate (Katherine J. Aucoin,et.al.).

Another longitudinal study found physical punishment during childhood to be significantly more prevalent among drug addicts (Baer \& Corrado, 1974).

\section{Mental Health Outcomes:-}

Corporal punishment to adverse physical, psychological and educational outcomes including, increased aggressive and destructive behavior, increased disruptive classroom behavior, vandalism, poor school achievement, poor attention span, increased dropout rate, school avoidance and school phobia, low self-esteem, anxiety, somatic complaints, depression, suicide and retaliation against teacher (Poole et al., 1991).

The use of corporal punishment (CP) likely affects children beyond the temporary pain inflicted. Serious psychological and emotional problems have been found to occur in children who have been the target of corporal punishment. These affects can influence one's life well into adulthood.

(Gershoff, 2002) revealed that Corporal punishment by parents has been associated with poorer mental health (i.e. depression, substance use, suicidal tendecy and low self-esteem) in childhood and adulthood.

A positive association has been found between the use of $\mathrm{CP}$ and psychological distress, specifically depressive symptoms. Students who witness or are victims of $\mathrm{CP}$ in school are at risk of developing a range of psychosocial problems, including depression, suicidal ideation and anxiety (Turner \& Finkelhor, 1996). CP has been determined to be a risk factor for future development of antisocial and violent behavior (Straus \& Mouradian, 1998).He was also stated that The long-term use of corporal punishment tends to increase the probability of deviant and antisocial behaviors, such as aggression; adolescent delinquency and violent acts inside and outside the school (Straus, 1991)

Corporal punishment causes psychological damages that are reflected obviously on child's self-esteem and self-confidence, and having other negative long-term personality effects (UNICEF, 2007). A study found out the negative side effects of punishment include running away; being truant; fearing teachers or school; feeling high levels of anxiety, helplessness, and humiliation; and being aggressive or destructive at home and school (Griffin, Robinson \& Carpenter, 2000).

A study revealed that corporal punishment affects child by not only inflicting physical pain but also mental harassment, feeling of helplessness, worthlessness, depression, inhibition, aggression, shame and selfdoubt, guilt, social with-drawl, feeling of inferiority, rigidity, lowered self-esteem, stress and heightened anxiety which may reduce his/her self confidence(Pandey2001).

Adolescents who have experienced corporal punishment show higher levels of depression and feelings of hopelessness as well as an increased propensity to use violence (DuRant et al., 1994).

A study founded that Children with behavior, anxiety, or disruptive disorders are more likely to report previous harsh physical punishment (Goodman et al., 1998).

3. Educational outcomes: - The use of corporal punishment in schools has been shown to be associated with damaging physical and psychological outcomes that can affect some children for the remainder of their lives. 
Emotional trauma from corporal punishment comprise of deterioration in family life, as parents were forced to withdraw students from school and resort to home schooling, depression, and an increase of violent behaviors (Dupper \& Dingus, 2008).

A study revealed that approximately one-half of students who are subjected to severe punishment develop an illness called Educationally Induced Post-Traumatic Stress Disorder (EIPSD). In this disorder, there is symptomatology analogous to the Post-Traumatic Stress Disorder (PTSD). As with PTSD, EIPSD can be identified by a varying combination of symptoms characteristic of depression and anxiety. This mental health imbalance is induced by significant stress; with EIPSD the stress is the inflicted punishment (Hyman et. al1996).

The student who received corporal punishment had difficulty in sleeping, fatigue, feelings of sadness and worthlessness, suicidal thoughts, anxiety episodes, increased anger with feelings of resentment and outbursts of aggression, deteriorating peer relationships, difficulty with concentration, lowered school achievement, antisocial behavior, intense dislike of authority, somatic complaints, tendency for school avoidance, school drop-out, and other evidence of negative high-risk adolescent behavior (Greydanus 2003).

The Punjab Education Department announced that incidents of corporal punishment in schools would not be tolerated and stern action would be taken against teachers who indulge in it under the Punjab Removal from Service Ordinance 2000 (Daily Times, 2005).

\section{Suggestion to reduce corporal punishment}

Educators and psychologists who oppose the use of Corporal punishment state that teachers should impose non physical disciplinary measures as an Alternative to beatings. They propose that teachers require students to write a statement describing the negative effects of their behavior to apologize for the mistakes in front of their classmates. Instructors can require the misbehaving child to sit on a chair or a mat at the back of the room and to think about his/her mistakes and of ways to improve his/her behavior (Human Rights Watch, 1999).

The National Commission for the Protection of Child Rights (2008) issued a set of guidelines on 'corporal punishment' and directs the education departments of all the States to ensure the following: -

1. All children are to be informed through campaigns and publicity drives that they have a right to speak against corporal punishment and bring it to the notice of the authorities. They must be given confidence to make complaints and not accept punishment as a 'normal' activity of the school.

2. Every school, including hostels, JJ Homes, shelter homes and other public institutions meant for children must have a forum where children can express their views. Such institutions could take the help of an NGO for facilitating such an exercise.

3. Further a box where children can drop their complaints, even if anonymous has to be provided in each school. 4. There has to be a monthly meeting of the PTAs or any other body such as the SEC/VEC to review the complaints and take action.

5. The PTAs are to be encouraged to act immediately on any complaints made by children without postponement of the issue and wait for a more grave injury to be caused. In other words the PTAs need not use their discretion to decide on the grievousness of the complaint.

6. Parents as well as children are to be empowered to speak out against corporal punishment without any fear that it would have adverse effect on children's participation in schools.

\section{Conclusion}

Every human being has a right to live without violence. We must not forget that children are human too. They have the same rights as everyone else - perhaps more so because given their age and ability, they do not have the strength and resources to fight for this right. It is the bounden duty of all adults and institutions to respect and protect children's rights. Over the past year many gruesome acts of corporal punishment have come to light - some of which resulted in the child's death. The use of violent behavior against students is never an acceptable means of punishment - it harms students physically, psychologically and academically. The use of corporal punishment in schools is interfering with students' right to be treated with dignity and, as a result, is interfering with their right to a quality education. Corporal punishment was not effective and that more effective disciplinary methods existed; most teachers do not use corporal Punishment, but many favor keeping it as an option and that smaller classes, increased parental Involvement, improved teacher training and the development of specific discipline plans would all help to improve student conduct. Teachers should be educated in the use of alternative methods of discipline, with an emphasis on employing evidence-based behavior modification and other techniques to maintain control of the classroom without resorting to violence. 


\section{Bibliography}

[1]. Straus MA, Mouradian VE: Impulsive corporal punishment by mothers and antisocial behavior and impulsiveness of children. Behav Sci Law 1998; 16:353-374.

[2]. Gershoff ET. Bitensky, SH: The case against corporal punishment of children: Converging evidence from social science research and international human rights law and implications for U.S. public policy. Psychology, Public Policy and Law. Nov 2007; 13(4): 231-272. ]

[3]. McClure TE, May DC: Dealing with Misbehavior at Schools in Kentucky: Theoretical and contextual predictors of use of corporal punishment. Youth \& Society Mar 2008; 39(3): 406-429.

[4]. Gershoff, E. T. Corporal punishment by parents and associated child behaviors and experiences: A meta-analytic and theoretical review. Psychological Bulletin, 2002,128, 539-579.

[5]. Turner, H. A. \& Finkelhor, D. Corporal punishment as a stressor among youth. Journal of Marriage and the Family, 1996 58, $155-$ 156.

[6]. Straus, M. A., \& Mouradian, V.E. Impulsive corporal punishment by mothers and antisocial behavior and impulsiveness of children. Behavioral Sciences and the Law,1998 16, 353-374.

[7]. UNICEF (2007): "Violence $\quad$ Children $\quad$ Study inst http://www.unicef.org/jordan/VAC Study English FOR SCREEN(1).

[8]. Joan Durrant and Ron Ensom. Physical punishment of children: lessons from 20 years of research. CMAJ, 2012 DOI: $10.1503 /$ cmaj.101314

[9]. Gershoff ET (2008). Report on Physical Punishment in the United States: What Research Tells Us About Its Effects on Children. Columbus OH: Center for Effective Discipline.

[10]. Vygotsky, L.S. (1978) Mind in Society: The Development of Higher Psychological Processes, Harvard University Press, Cambridge, Massachusetts.

[11]. Robinson, D. H., Funk, D. C., Beth, A., \& Bush, A. MChanging beliefs about corporal punishment: Increasing knowledge about ineffectiveness to build more consistent moral and

[12]. informational beliefs. Journal of Behavioral Education, (2005) 14, 117-13 9

[13]. Andero, A. A., \& Stewart, A. Issues of corporal punishment: Re-examined. Journal of Instructional Psychology, (2002) 29, 90-96

[14]. Katherine J. Aucoin et.al. Corporal punishment and child adjustment Journal of Applied Developmental Psychology 27 (2006) $527-541$

[15]. Dupper, D. R., \& Dingus, A. E. Corporal punishment in U.S. public schools: A continuing challenge for school social workers. Children \& Schools, (2008) 30(4), 243-250.

[16]. Hyman IA: Using research to change public policy: Reflections on 20 years of effort eliminate corporal punishment in schools. Pediatrics 1996; 98 (Suppl):818-821.

[17]. Hyman IA, McDowell E, Rains B: Corporal punishment and alternatives in the schools: An overview of theoretical and practical issues in National Institute of Education: Proceedings: Conference on Corporal Punishment Schools: A National Debate, February 18-20, 1977, U.S. Government Printing Office, 729 222/565, 1977.

[18]. Greydanus DE, Pratt HD, Spates CR, Blake-Dreher AE, Greydanus-Gearhart MA, Patel DR: Corporal punishment: Position Statement of Society for Adolescent Medicine. J Adolesc Health 32:385-393, 2003.

[19]. Pandey, S. Corporal punishment in schools. New Front in Educ, (2001) 31: 347-354.

[20]. Straus, Murray. A Discipline and Deviance: Physical Punishment of Children and Violence and Other Crime in Adulthood: Social Problems (1991) 38 (2):205-206.

[21]. Daily Times. (July 4, 2005). Staff Report, Corporal Punishment.

[22]. DuRant, R.H., Cadenhead, C., Pendergrast, R.A., Slavens, G., \& Linder, C.WFactors associated with the use of violence among urban Black adolescents. American Journal of Public Health, (1994) 84, 612-617.

[23]. Goodman, S.H., Hoven, C.W., Narrow, W.E., Cohen, P., Fielding, B., Alegria, M., et al. Measurement of risk for mental disorders and competence in a psychiatric epidemiologic community survey: The National Institute of Mental Health Methods for the Epidemiology of Child and Adolescent Mental Disorders (MECA) study. Social Psychiatry and Psychiatric Epidemiology, (1998) 33, 162-173.

[24]. Baer, D. J., \& Corrado, J. J. Heroin addict relationships with parents during childhood early adolescent years. Journal of Genetic Psychology, (1998). 124, 99-103.

[25]. NATIONAL COMMISSION FOR THE PROTECTION OF CHILD RIGHTS Delhi, December 2008 Working Group on Protection of Children against Corporal Punishment in Schools an Institution .

[26]. Cities.expressindia.com, 7 April 2007.

[27]. Ministry of women and child development, a study on child abuse in India 2007 new Delhi.

[28]. UNESCO. (2001). Monitoring report on education for all 2001. Retrieved 08th September http://www.unesco.org/education/efa/monitoring/monitoring_rep_contents.shtml.

[29]. Johnston, T. (2004). Gender Series: The abuse of Nairobi school children, Nairobi: Population Communication Africa, in O'Sullivan, M. (2005), Corporal punishment in Kenya, Juvenile Justice Quarterly, 2, 1.

[30]. Agbenyega, J. S. 2006. Corporal punishment in the schools of Ghana: Does inclusive education suffer? The Australian Educational Researcher, 33(3), 107-122.

[31]. Human Rights Watch. (1999), Spare the child: Corporal punishment in Kenyan School. Retrieved 21 st November 2011 from http://www.unhcr.org/refworld/docid/45d1adbc2.html. 